Article

\title{
Synthesis, Properties, and Biodegradation of Sequential Poly(Ester Amide)s Containing $\gamma$-Aminobutyric Acid
}

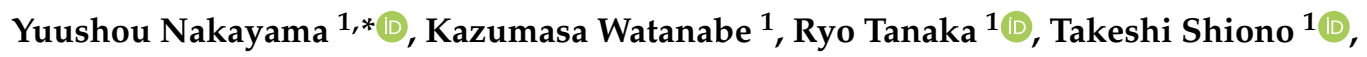 \\ Norioki Kawasaki ${ }^{2}$, Naoko Yamano ${ }^{2}$ and Atsuyoshi Nakayama ${ }^{2}$ \\ 1 Department of Applied Chemistry, Graduate School of Engineering, Hiroshima University, \\ 1-4-1 Kagamiyama, Higashi-Hiroshima, Hiroshima 739-8527, Japan; m173038@hiroshima-u.ac.jp (K.W.); \\ rytanaka@hiroshima-u.ac.jp (R.T.); tshiono@hiroshima-u.ac.jp (T.S.) \\ 2 Biomedical Research Institute, National Institute of Advanced Industrial Science and Technology (AIST), \\ 1-8-31 Midorigaoka, Ikeda, Osaka 563-8577, Japan; n-kawasaki@aist.go.jp (N.K.); \\ yamano.naoko@aist.go.jp (N.Y.); a.nakayama@aist.go.jp (A.N.) \\ * Correspondence: yuushou@hiroshima-u.ac.jp; Tel.: +81-82-424-7746
}

Received: 30 April 2020; Accepted: 20 May 2020; Published: 23 May 2020

\begin{abstract}
Poly(ester amide)s are attracting attention because they potentially have excellent thermal and mechanical properties as well as biodegradability. In this study, we synthesized a series of novel poly(ester amide)s by introducing $\gamma$-aminobutyric acid (GABA) regularly into polyesters, and investigated their properties and biodegradabilities. GABA is the monomer unit of biodegradable polyamide 4 (PA4). The new poly(ester amide)s were synthesized from the reaction of ammonium tosylate derivatives of alkylene bis( $\gamma$-aminobutylate) and $p$-nitrophenyl esters of dicarboxylic acids. All the obtained polymers showed relatively high melting temperatures $\left(T_{\mathrm{m}}\right)$. Their thermal decomposition temperatures were improved in comparison with that of PA4 and higher enough than their $T_{\mathrm{m}}$. The poly(ester amide)s exhibited higher biodegradability in seawater than the corresponding homopolyesters. Their biodegradabilities in activated sludge were also studied.
\end{abstract}

Keywords: poly(ester amide)s; $\gamma$-aminobutyric acid; thermal properties; biodegradation; seawater; activated sludge

\section{Introduction}

Biodegradable polymers are attracting attention due to recent environmental problems caused by wasted polymer materials [1-4]. Bacterial aliphatic polyesters such as poly(3-hydroxyalkanoate)s (PHAs) and synthetic polyesters such as poly(L-lactic acid) (PLLA), poly(glycolic acid) (PGA), poly(e-caprolactone) (PCL), and poly(butylene succinate) (PBS) are representative biodegradable polymers. In recent years, marine pollution by microplastics has become a worldwide issue [5-7]. Therefore, the polymers biodegradable in seawater should be useful for the applications where the complete recovery of the materials is difficult. Among the so-called biodegradable polymers, ones degradable in seawater are limited. PHAs and PGA are the representative examples reported to be biodegradable in seawater [8-10]. In contrast, aromatic polyesters such as poly(ethylene terephthalate) (PET) are not recognized as biodegradable polymers, although some microorganisms were reported to degrade PET [11]. We have recently reported a series of aliphatic-aromatic copolyesters with periodic sequences, where the copolyesters with glycolate units, poly((ethylene diglycolate) terephthalate), exhibited biodegradability in seawater, while the corresponding copolyester with L-lactate was hardly degradable [12]. These results could be related to high and low biodegradability of PGA [13] and PLLA $[10,14-16]$ in seawater, respectively. 
On the other hand, polyamides (nylons) such as polyamide 6 (6-nylon) are also widely used for their high water absorption, crystallinity, chemical resistance, high melting point, strength, and flexibility derived from intra- and intermolecular hydrogen bond of amide groups. However, the commercially available polyamides are made from fossil resources and hardly biodegradable. In contrast, polyamide 4 (PA4) can be obtained from bio-based $\gamma$-aminobutyric acid (GABA), which can be produced by fermentation of glutamic acid [17]. PA4 is also reported to be biodegradable in various media including seawater [18-23]. However, PA4 has a disadvantage of relatively low thermal stability, which can be somewhat improved by end-group modification [24].

Poly(ester amide)s are polymers having both ester and amide bonds in their polymer main chains [25-34]. Poly(ester amide)s with aliphatic ester moieties can possess both biodegradability for aliphatic ester bonds and excellent physical properties due to the amide bonds. Poly(ester amide)s with various monomer combinations have been synthesized and investigated for their thermal, mechanical properties and degradability. Bayer has commercialized poly(ester amide) (BAK 1095) that consists of 1,4-butanediol, adipic acid, and $\varepsilon$-caprolactam, which possesses complete biodegradability as well as excellent thermal and mechanical properties and processability [35]. Several poly(ester amides) containing $\alpha$-amino acids have been studied due to their enzymatic degradability $[30,33,36]$.

As PA4 has been reported to be biodegradable in seawater [22,37], we expected that the poly(ester amide)s containing GABA units could also be the polymers biodegradable in seawater. In addition [38], the copolymers with regular sequences such as alternating and periodic copolymers could have some specific properties such as higher melting temperature $\left(T_{\mathrm{m}}\right)$ and/or glass-transition temperature $\left(T_{\mathrm{g}}\right)$ not expected from those of the corresponding homopolymers [39], in comparison with the corresponding random copolymers $[12,25,34,38]$. In this study, we synthesized a series of new sequential poly(ester amide)s containing GABA unit and investigated their thermal properties and biodegradabilities in seawater and in activated sludge.

\section{Results}

\subsection{Synthesis of the Sequential Poly(Ester Amide)s}

In this study, the sequential poly(ester amide)s containing GABA unit were synthesized in a similar procedure for those containing $\alpha$-amino acids $[30,40]$. For this purpose, tosylates of alkylene bis $(\gamma$-aminobutyrate)s and $p$-nitrophenyl esters of dicarboxylic acids were prepared from the reactions shown in Schemes 1 and 2, respectively. The 2:2:1 reaction of GABA, $p$-toluenesulfonic acid monohydrate $\left(\mathrm{TsOH} \cdot \mathrm{H}_{2} \mathrm{O}\right)$, and alkanediol in toluene gave the corresponding tosylates of alkylene bis $(\gamma$-aminobutyrate)s, gEg-OTs (alkylene $=$ ethylene $)$, gPg-OTs (alkylene $=$ trimethylene $)$, and gBg-OTs (alkylene $=$ tetramethylene) in good yields after recrystallization from ethanol. On the other hand, the chloride derivatives of dicarboxylic acids such as terephthalic acid, 2,6-naphthalenedicarboxylic acid, succinic acid, glutaric acid, and adipic acid were reacted with $p$-nitrophenol in the presence of $\mathrm{Et}_{3} \mathrm{~N}$ to produce the corresponding $p$-nitrophenyl esters, T-NP, N-NP, S-NP, Gl-NP, and A-NP, respectively [41-44].



Scheme 1. Synthesis of tosylates of alkylene $\gamma$-aminobutyrates.

Polycondensation of the tosylates of alkylene bis( $\gamma$-aminobutyrate)s and the $p$-nitrophenyl esters of dicarboxylic acids in dimethyl sulfoxide (DMSO) was performed to produce sequential poly(ester amide)s (Scheme 3, Table 1). The poly(ester amide)s were obtained in good yields, due to the $p$-nitrophenol moiety acting as a good leaving group to promote the polymerization. The obtained poly(ester amide)s were poorly soluble in common organic solvents (tetrahydrofuran (THF), $\mathrm{CHCl}_{3}$ ), 
so 1,1,1,3,3,3-hexafluoro-2-propanol (HFIP) was used as an eluent in gel permeation chromatography (GPC) analysis calibrated with standard poly(methyl methacrylate)s. Their molecular weights were $M_{\mathrm{n}}=2600-7600 \mathrm{~g} / \mathrm{mol}$. The polymerization reactions using different solvent such as tetrachloroethane, dimethylformamide, and $\mathrm{N}$-methylpyrrolidone or longer reaction time $(48 \mathrm{~h})$ were also tested, however, the polymer yields and molecular weights were not improved.

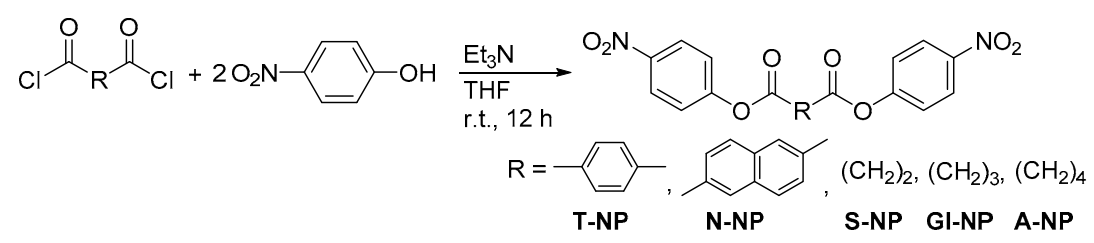

Scheme 2. Synthesis of $p$-nitrophenyl esters of dicarboxylic acids.

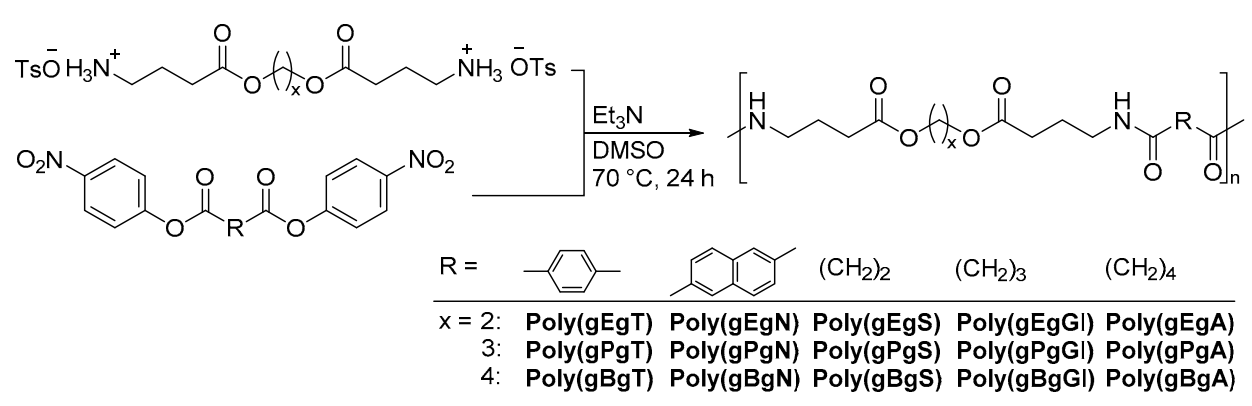

Scheme 3. Polycondensation of the tosylates and the $p$-nitrophenyl esters to produce sequential poly(ester amide)s.

Table 1. Synthesis of sequential poly(ester amide)s.

\begin{tabular}{|c|c|c|c|c|c|c|c|}
\hline \multirow[t]{2}{*}{ Entry } & \multirow[t]{2}{*}{ Polymer } & \multirow[t]{2}{*}{$x$} & \multirow{2}{*}{$R$} & \multirow{2}{*}{$\begin{array}{c}\text { Yield } \\
(\%)\end{array}$} & \multirow{2}{*}{$\frac{M_{\mathrm{n}}{ }^{a}}{(\mathrm{~g} / \mathrm{mol})}$} & \multirow{2}{*}{$\frac{M_{\mathrm{w}}{ }^{a}}{(\mathrm{~g} / \mathrm{mol})}$} & \multirow{2}{*}{$M_{\mathrm{w}} / M_{\mathrm{n}}{ }^{a}$} \\
\hline & & & & & & & \\
\hline 1 & Poly(gEgT) & 2 & p-phenylene & 72 & 2600 & 4100 & 1.6 \\
\hline 2 & Poly(gPgT) & 3 & $p$-phenylene & 92 & 6500 & 13,800 & 2.1 \\
\hline 3 & Poly(gBgT) & 4 & $p$-phenylene & 80 & 4900 & 8300 & 1.7 \\
\hline 4 & Poly(gEgN) & 2 & 2,5-naphthalenediyl & 92 & 5000 & 9900 & 2 \\
\hline 5 & Poly(gPgN) & 3 & 2,5-naphthalenediyl & 97 & 5500 & 12,400 & 2.2 \\
\hline 6 & Poly(gBgN) & 4 & 2,5-naphthalenediyl & 96 & 4900 & 8800 & 1.8 \\
\hline 7 & Poly(gEgS) & 2 & $\left(\mathrm{CH}_{2}\right)_{2}$ & 86 & 6100 & 12,400 & 2 \\
\hline 8 & Poly(gPgS) & 3 & $\left(\mathrm{CH}_{2}\right)_{2}$ & 83 & 5700 & 10,700 & 1.9 \\
\hline 9 & Poly(gBgS) & 4 & $\left(\mathrm{CH}_{2}\right)_{2}$ & 79 & 7600 & 15,300 & 2 \\
\hline 10 & Poly(gEgGl) & 2 & $\left(\mathrm{CH}_{2}\right)_{3}$ & 77 & 4100 & 10,500 & 2.6 \\
\hline 11 & Poly(gPgGl) & 3 & $\left(\mathrm{CH}_{2}\right)_{3}$ & 88 & 6700 & 17,800 & 2.7 \\
\hline 12 & Poly(gBgGl) & 4 & $\left(\mathrm{CH}_{2}\right)_{3}$ & 83 & 5700 & 14,900 & 2.6 \\
\hline 13 & Poly(gEgA) & 2 & $\left(\mathrm{CH}_{2}\right)_{4}$ & 83 & 4400 & 11,000 & 2.5 \\
\hline 14 & Poly(gPgA) & 3 & $\left(\mathrm{CH}_{2}\right)_{4}$ & 83 & 7300 & 18,700 & 2.5 \\
\hline 15 & Poly(gBgA) & 4 & $\left(\mathrm{CH}_{2}\right)_{4}$ & 78 & 6600 & 15,500 & 2.3 \\
\hline
\end{tabular}

${ }^{a}$ Determined by GPC calibrated with PMMA standard in HFIP.

Figure 1 shows the ${ }^{1} \mathrm{H}$ NMR spectrum of the obtained poly((butylene bis( $\gamma$-aminobutyrate) $)$ succinate) (poly(gBgS)) for example. The observed seven signals can be assigned to the protons of the expected repeating unit, indicating the successful formation of the target poly(ester amide) with periodic sequence. 


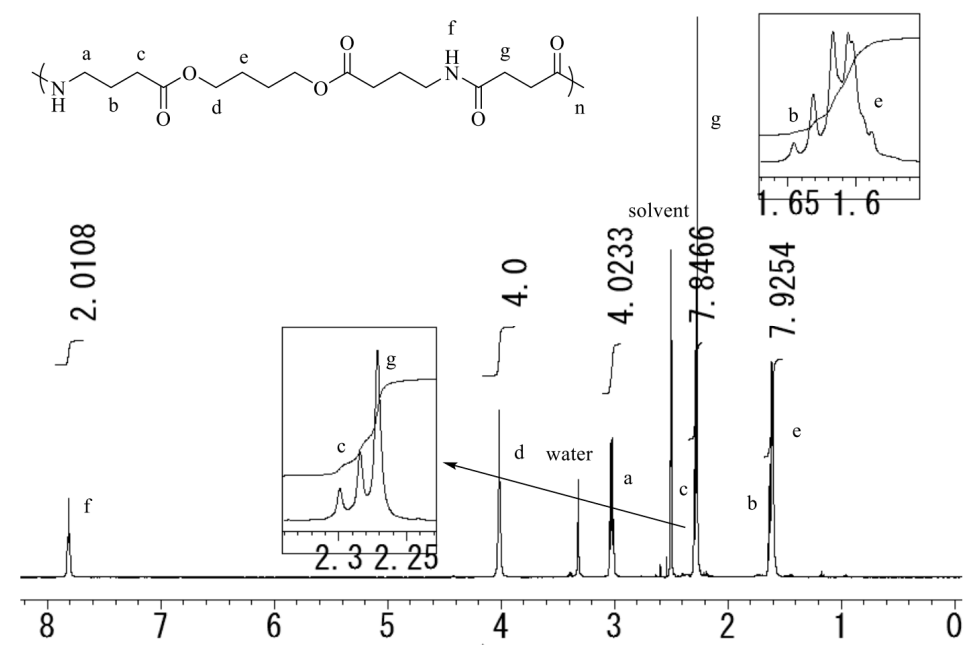

Figure 1. ${ }^{1} \mathrm{H}$ NMR spectrum of poly(gBgS) (DMSO- $\left.d_{6}, 500 \mathrm{MHz}, \mathrm{R} . \mathrm{T}.\right)$.

\subsection{Thermal Properties of the Poly(Ester Amide)s Containing GABA Unit}

We performed the differential scanning calorimetry (DSC) analysis of the obtained poly(ester amides)s to reveal their thermal properties, and the results are summarized in Table 2. All the polymers exhibited multiple melting transitions indicating their multiple crystal structures (Figure S19). Aromatic poly(ester amide)s containing terephthalate (entries 1-3) or 2,6-naphthalenedicarboxylate (entries 4-6) units exhibited relatively high $T_{\mathrm{m}}$ over $200^{\circ} \mathrm{C}$. Aliphatic poly(ester amide)s possessed $T_{\mathrm{m}}$ from 111 to $181{ }^{\circ} \mathrm{C}$. Among them, the $T_{\mathrm{m}}$ values of glutarate polymers were lower than those of succinate and adipate polymers. Similar odd-even effects are known for simple aliphatic polyesters [45,46]. The poly(ester amide)s exhibited $T_{\mathrm{g}}$ from 71 to $103^{\circ} \mathrm{C}$.

Table 2. Thermal properties of the sequential poly(ester amide)s.

\begin{tabular}{|c|c|c|c|c|c|c|}
\hline \multirow{2}{*}{ Entry } & \multirow{2}{*}{ Polymer } & $T_{\mathrm{g}}{ }^{a}$ & $T_{\mathrm{m}}{ }^{a}$ & $\Delta H_{\mathrm{m}}{ }^{a}$ & $T_{\mathrm{d} 5}{ }^{b}$ & $T_{\mathrm{d} 10}{ }^{b}$ \\
\hline & & $\left({ }^{\circ} \mathrm{C}\right)$ & $\left({ }^{\circ} \mathrm{C}\right)$ & $(\mathrm{J} / \mathrm{g})$ & $\left({ }^{\circ} \mathrm{C}\right)$ & $\left({ }^{\circ} \mathrm{C}\right)$ \\
\hline 1 & Poly(gEgT) & 103 & 212,238 & $9.6,11.0$ & 302 & 320 \\
\hline 2 & Poly(gPgT) & 75 & 200,218 & $5.6,8.6$ & 276 & 294 \\
\hline 3 & Poly(gBgT) & 72 & 188,207 & $13.4,5.2$ & 268 & 280 \\
\hline 4 & Poly(gEgN) & 84 & 229,238 & 10.6 & 290 & 300 \\
\hline 5 & Poly(gPgN) & 90 & 218,232 & $5.6,6.2$ & 297 & 311 \\
\hline 6 & Poly(gBgN) & 71 & 217,236 & 14.2 & 300 & 315 \\
\hline 7 & Poly(gEgS) & 71 & 165,181 & 17 & 245 & 274 \\
\hline 8 & Poly(gPgS) & 84 & 146,166 & $11.0,8.2$ & 259 & 277 \\
\hline 9 & Poly(gBgS) & 79 & 152,172 & $11.1,7.9$ & 264 & 278 \\
\hline 10 & Poly(gEgGl) & 78 & 112,133 & $1.2,11.0$ & 269 & 284 \\
\hline 11 & Poly(gPgGl) & 74 & 121,140 & $13.1,0.6$ & 269 & 281 \\
\hline 12 & Poly(gBgGl) & 77 & 111,128 & $12.7,1.1$ & 271 & 289 \\
\hline 13 & Poly(gEgA) & 75 & 162 & 19.2 & 279 & 292 \\
\hline 14 & Poly(gPgA) & 82 & $140,151,162$ & $18.4,3.3$ & 295 & 310 \\
\hline \multirow[t]{4}{*}{15} & Poly(gBgA) & 79 & 148,162 & $15.0,3.7$ & 279 & 290 \\
\hline & PET [47] & 81 & $240-260$ & & 396 & \\
\hline & PA4 [47,48] & & $240-260$ & & 236 & \\
\hline & PBS [47] & & 113 & & & \\
\hline
\end{tabular}

The thermal degradation behaviors of the poly(ester amide)s were measured by thermogravimetric analysis (TG). The TG profiles of the poly(ester amide)s with gEg moiety are shown in Figure 2 for example, and those of others are included in the Supplementary Materials. All the poly(ester amide)s exhibited two stage thermal degradation behaviors. The degradation temperatures at $5 \%$ weight loss $\left(T_{\mathrm{d} 5}\right)$ and $10 \%$ weight loss $\left(T_{\mathrm{d} 10}\right)$ are included in Table 2. 


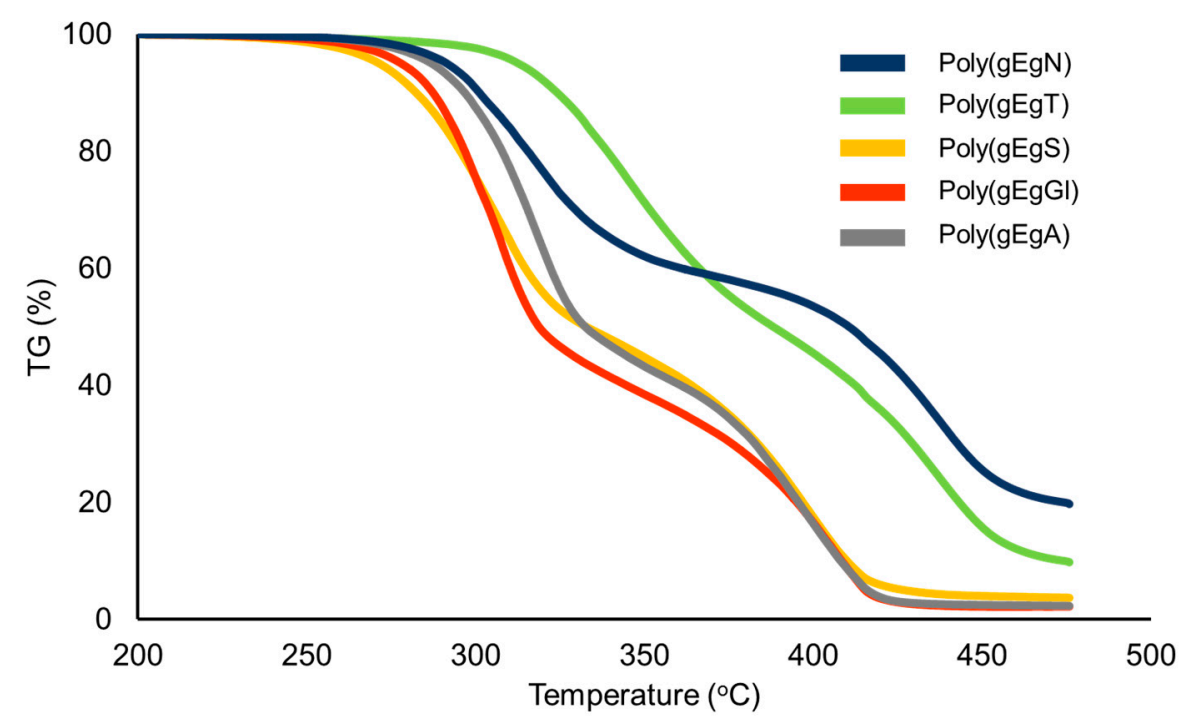

Figure 2. Thermogravimetric analysis (TG) curves of the selected poly(ester amide)s with gEg components.

\subsection{Biodegradation of the Poly(Ester Amide)s Containing GABA Unit}

Biodegradation tests were carried out in seawater and in activated sludge using the selected samples of the obtained poly(ester amide)s at $27^{\circ} \mathrm{C}$ for one month. The biodegradation was monitored by the amount of the consumed oxygen. Based on the theoretical value of the amount of oxygen required for complete oxidation, which was calculated from the structure of each poly(ester amide), the degree of biodegradation was determined. A representative biodegradable polymer, poly(3-hydroxybutyrate) (PHB), was used as a reference sample.

The results of the biodegradation of the poly(ester amide)s in seawater are summarized in Figure 3. The poly(ester amide)s having ethylene glycol and aliphatic dicarboxylic acid units showed a biodegradation of ca. $30 \%$ after 30 days, similarly to PA4 homopolyer [37]. Poly(gPgS) with a C3 diol and succinate units also showed similar biodegradation to that of poly $(\mathrm{gEgS})$. The biodegradation of poly $(\mathrm{gBgS})$ and aromatic poly(ester amide)s were slower than those of the other poly(ester amide)s.

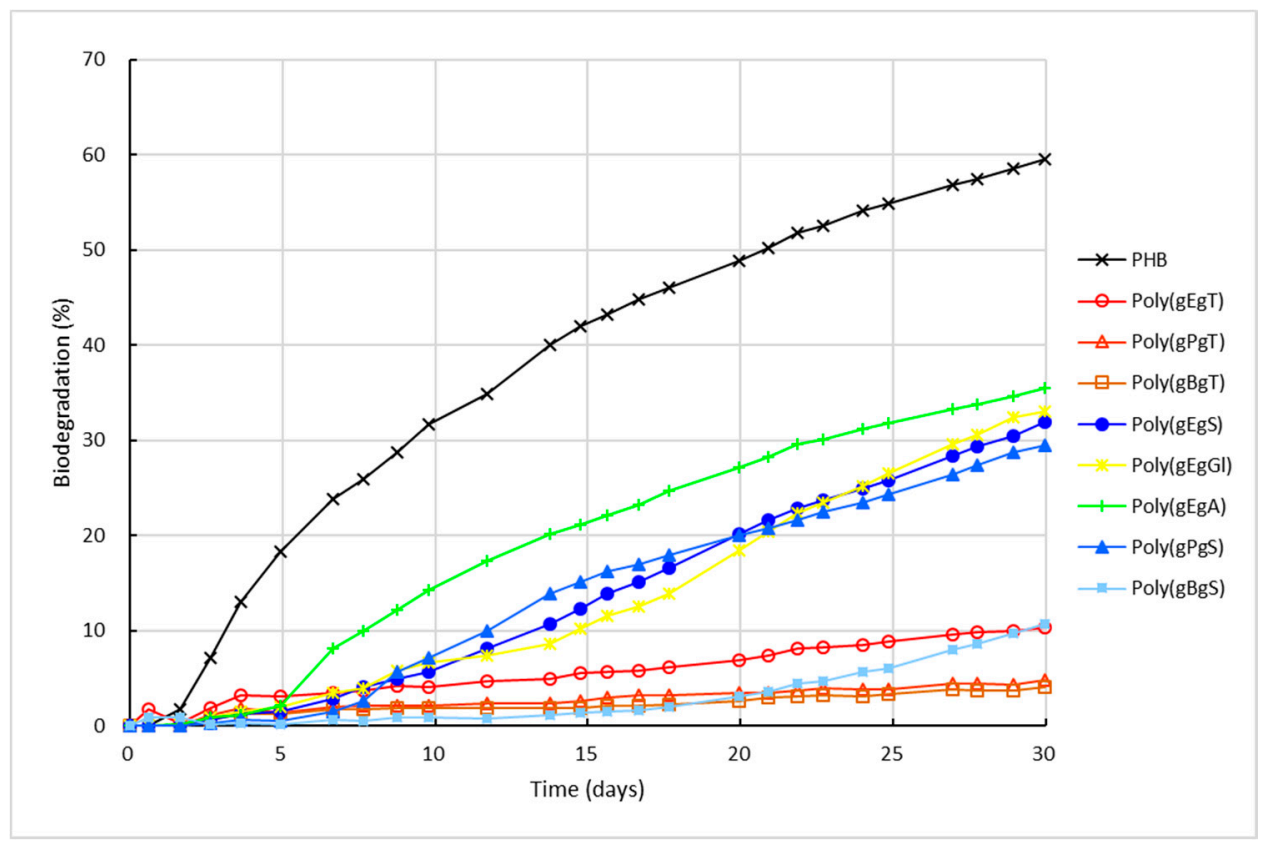

Figure 3. Biodegradation of the poly(ester amide)s in seawater. 
Figure 4 shows the results of the biodegradation tests of the poly(ester amide)s in activated sludge. Although the biodegradation of the poly(ester amide)s were slower than that of PHB, the poly(ester amide)s with ethylene glycol unit were degraded significantly, as is the case in seawater. The other poly(ester amide)s were considerably less degraded than the aliphatic poly(ester amide)s with ethylene glycol units.

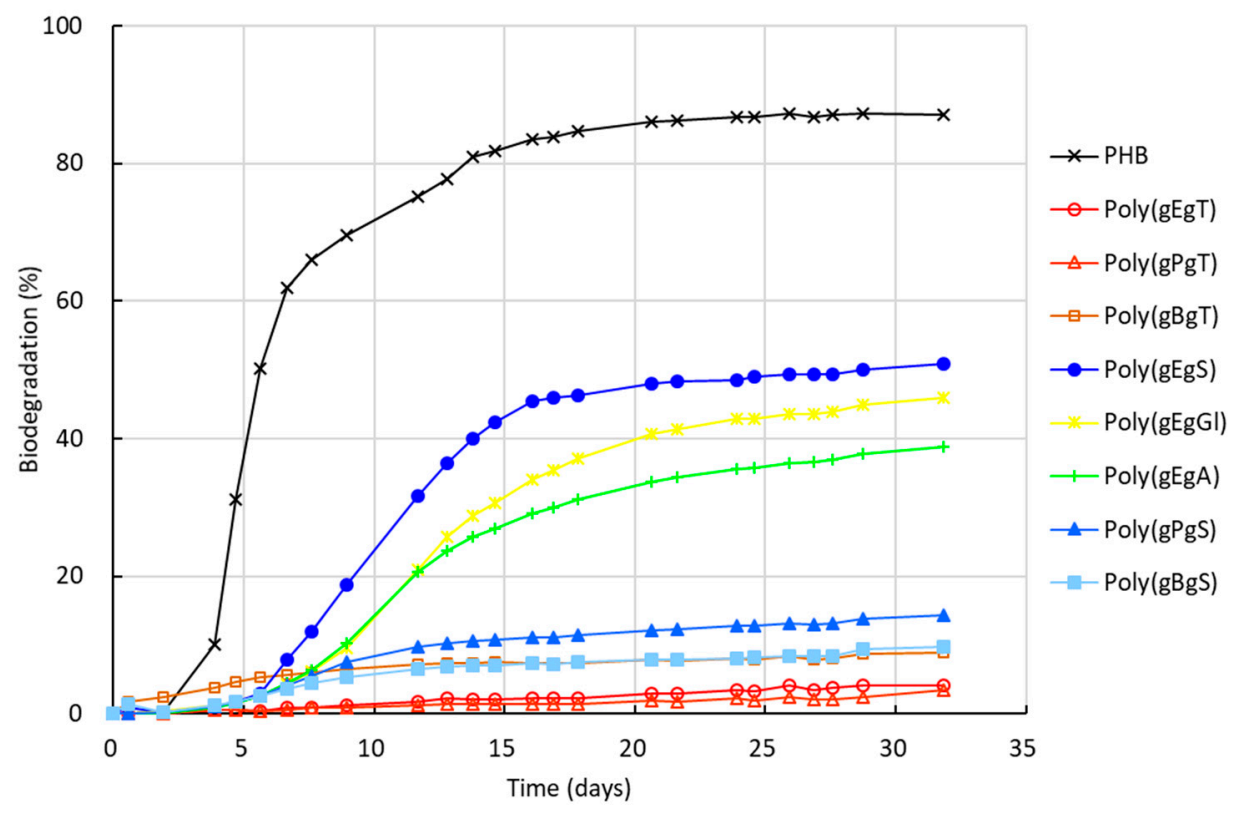

Figure 4. Biodegradation of the poly(ester amide)s in activated sludge.

\section{Discussion}

We examined several synthetic methods to synthesize poly((ethylene bis( $\gamma$-aminobutyrate)) terephthalate) (poly(gEgT)). At first, we tried to synthesize poly(gEgT) by the reaction of ethylene bis( $\gamma$-aminobutyrate) (gEg) and terephthaloyl chloride. However, the purification of gEg was difficult because of its low stability, which resulted in low polymer yield and low molecular weight of the product. We also tested the polycondensation of dimethyl 4,4'-(terephthaloylbis(azanediyl))dibutyrate with ethylene glycol, but a significant amount of GABA component was lost during the reaction, possibly due to the formation of 2-pyrolidone. The solution polycondensation of the tosylates of alkylene $\gamma$-aminobutyrates and $p$-nitrophenyl esters of dicarboxylic acids resulted in better yields and structural regularities of the obtained poly(ester amide)s, possibly due to high reactivities of the reactants at relatively low temperature. The molecular weights of the obtained poly(ester amide)s still remained low to middle, which could be attributed to the purity of the reactants and/or relatively low solubility of the resulting polymers. The aliphatic poly(ester amide)s tended to have slightly higher molecular weights than those with aromatic components, this could come from the better solubility of the former.

The poly(ester amide)s with GABA showed multiple melting transitions, and a similar behavior was observed for other reported poly(ester amide)s $[26,36]$. This could be related to the liquid crystalline property, although not investigated in this study [26]. The $T_{\mathrm{m}}$ over $200{ }^{\circ} \mathrm{C}$ of the aromatic poly(ester amide)s are lower than those of the corresponding homopolyesters and PA4 but significantly higher than those of aliphatic poly(ester amide)s. The $T_{\mathrm{m}}$ values of the aliphatic poly(ester amide)s are higher than that of $\mathrm{PBS}\left(\approx 113^{\circ} \mathrm{C}\right)$, which has the highest melting point among the polyesters of type $\left(\mathrm{O}\left(\mathrm{CH}_{2}\right)_{\mathrm{x}} \mathrm{OCO}\left(\mathrm{CH}_{2}\right)_{\mathrm{y}} \mathrm{CO}\right)_{\mathrm{n}}(\mathrm{x}=2-4, \mathrm{y}=2-4)$ [47]. These results demonstrated that the sequential introduction of GABA units into aliphatic polyesters effectively enhance their $T_{\mathrm{m}}$ values.

The poly(ester amide)s showed two stage decomposition behavior in TG. Similar two step thermal degradation behaviors were observed for some reported poly(ester amide)s, where the first degradation 
step was assigned to the ester bond cleavage $[34,49,50]$. All the poly(ester amide)s showed higher $T_{\mathrm{d} 5}$ values than that of PA4 [24] as indicated in Table 2. The $T_{\mathrm{m}}$ and $T_{\mathrm{d} 5}$ values of the poly $(\mathrm{gEgT})$, poly $(\mathrm{gBgS})$, and PA4 are shown for example in Figure 5. PA4 has a higher $T_{\mathrm{m}}$ than its $T_{\mathrm{d} 5}$. Therefore, PA4 has the difficulty in its thermal molding. In sharp contrast, $T_{\mathrm{d} 5}$ values of the poly $(\mathrm{gEgT})$ and poly $(\mathrm{gBgS})$ are higher enough than their $T_{\mathrm{m}}$, indicating their excellent thermoformability.

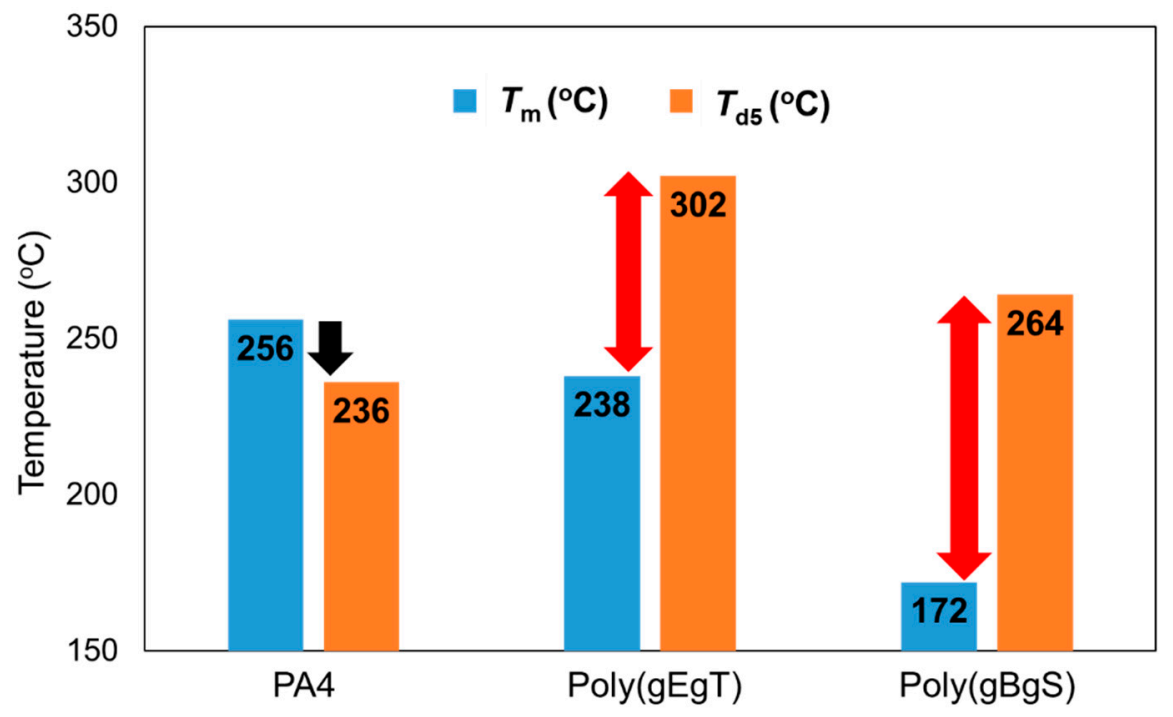

Figure 5. Comparison of melting and decomposition temperatures for the poly(ester amide)s. Black arrow: $T_{\mathrm{m}}>T_{\mathrm{d} 5}$. Red arrow: $T_{\mathrm{m}}<T_{\mathrm{d} 5}$.

The observed biodegradation of the poly(ester amide)s in seawater after 30 days are summarized in Figure 6. The biodegradation of poly(ethylene succinate) (PES) and PBS in seawater was reported to be slow, where only $1-3 \%$ of those polymers were degraded after 28 days [10,51]. PET is hardly degradable in seawater over a year [9]. In contrast, biodegradation of poly (gEgS), poly(gBgS), and poly(gEgT) reached $30 \%, 10 \%$, and $10 \%$, respectively, although the conditions of these degradation tests are not completely the same as the cited references. These data suggest that the presence of GABA moiety in repeating units can enhance the biodegradability of the polymers in seawater, although rather low molecular weights of the poly(ester amide)s could somewhat contribute to their biodegradation, especially for poly (gEgT) $\left(M_{n}=\right.$ only 2600$)$. The biodegradation of poly $(\mathrm{gBgS})$ was much slower than those of poly (gEgS) and poly(gPgS), possibly due to the lower hydrophilicity of poly (gBgS). On the other hand, poly (gEgS), poly (gEgGl), and poly (gEgA) exhibited similar biodegradability. It is noteworthy that the biodegradation of poly (gEgA) was considerably faster than that of poly (gBgS) with the same composition. These results imply that the shorter diol unit is more important than the shorter dicarboxylate unit for faster biodegradation of the aliphatic poly(ester amide)s in seawater, although lower molecular weight of poly $(\mathrm{gEgGl})$ and poly $(\mathrm{gEgA})$ could also enhance their biodegradation. We assume that the ester bonds between diol and GABA units could be preferentially hydrolyzed rather than the amide bonds between GABA and dicarboxylate in the biodegradation of the poly(ester amide)s. This could explain the reason why the structure of the diol unit of the poly(ester amide)s has a critical effect on their biodegradation.

The observed biodegradation of the poly(ester amide)s in activated sludge after 32 days are summarized in Figure 7. As is the case in seawater, aliphatic poly(ester amide)s with ethylene glycol units were clearly more biodegradable than other poly(ester amide)s. Poly(gPgS) was less degradable in activated sludge than in seawater. The degradability of poly $(\mathrm{gEgS})$ seems to be similar to those reported for PES [52] and PA4 [19], while that of poly(gBgS) seems to be lower than that of PBS [53], although the conditions are not the same. 


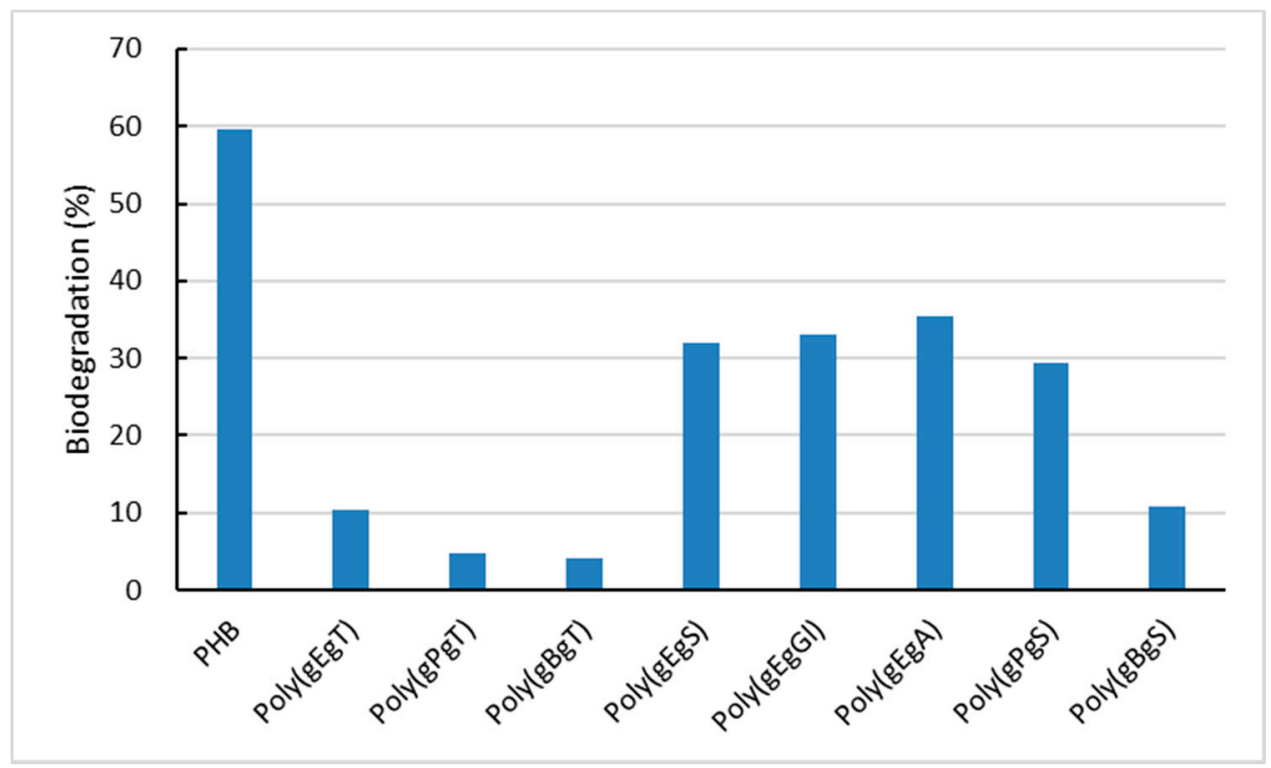

Figure 6. Biodegradation of the poly(ester amide)s in seawater after 30 days.

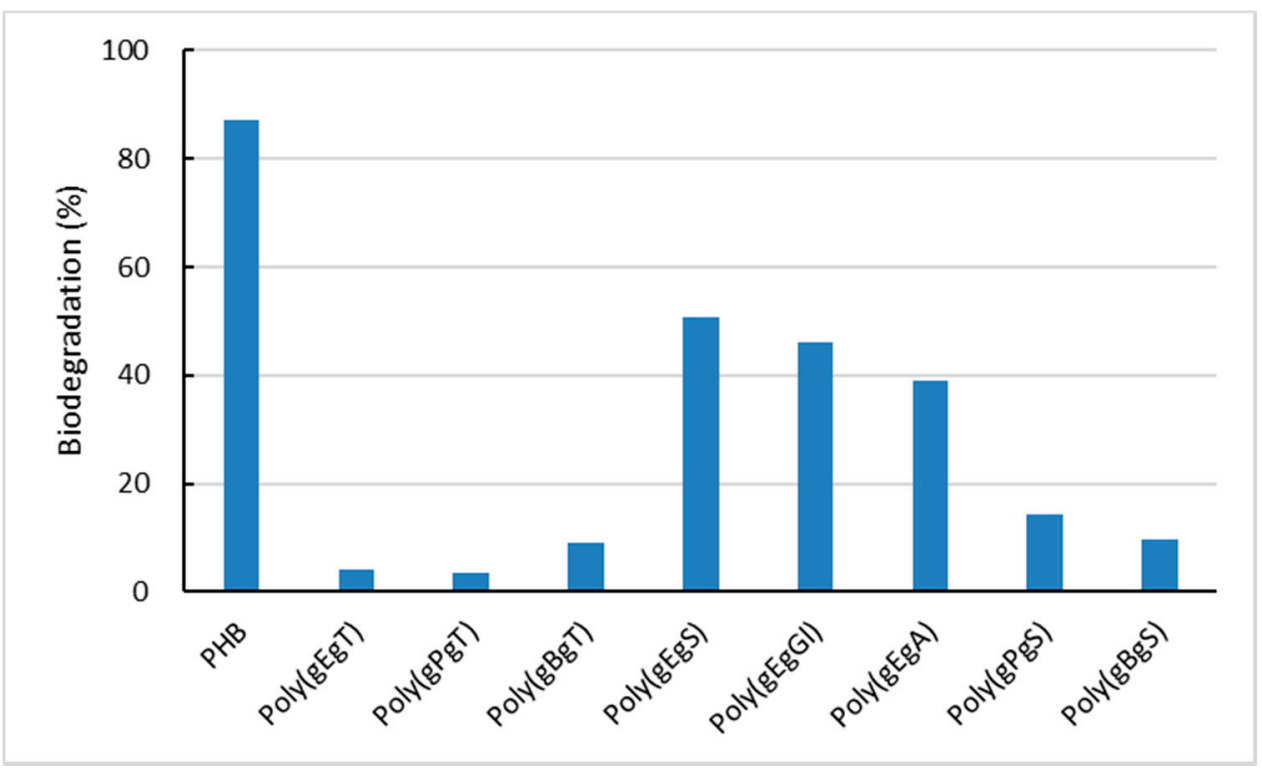

Figure 7. Biodegradation of the poly(ester amide)s in activated sludge after 32 days.

\section{Materials and Methods}

\subsection{Chemicals}

All organic solvents were purified by distillation under nitrogen prior to use. Ethylene glycol (EG), 1,3-propanediol (PDO), 1,4-butanediol (BDO), and triethylamine ( $\left.\mathrm{Et}_{3} \mathrm{~N}\right)$ (Tokyo Chemical Industry Co, Tokyo, Japan) were distilled under vacuum and stored on molecular sieves $4 \mathrm{~A}$. $p$-Toluenesulfonic acid monohydrate $\left(\mathrm{TsOH} \cdot \mathrm{H}_{2} \mathrm{O}\right)$, thionyl chloride $\left(\mathrm{SOCl}_{2}\right)$, ethyl acetate (EtOAc), $\gamma$-aminobutyric acid (GABA), terephthaloyl chloride (TC), succinyl chloride (SC), glutaryl chloride (GC), adipoyl chloride (AC), 2,6-naphthalenedicarboxylic acid (NA), and $p$-nitrophenol were purchased from Tokyo Chemical Industry Co. Bis( $p$-nitrophenyl) terephthalate (T-NP) [41], bis ( $p$-nitrophenyl) 2,6-naphthalenedicarboxylate (N-NP) [42], bis( $p$-nitrophenyl) succinate (S-NP) [41], bis ( $p$-nitrophenyl) glutarate (G-NP) [43], and bis(p-nitrophenyl) adipate (A-NP) [44], were prepared according to the literature. 


\subsection{Measurements}

${ }^{1} \mathrm{H}$ NMR spectra were recorded on a Varian System 500 spectrometer (Agilent, Santa Clara, CA, USA) (500 MHz for ${ }^{1} \mathrm{H}$ nucleus). Chemical shifts of ${ }^{1} \mathrm{H}$ NMR spectra were calibrated by using residual proton in $\mathrm{CDCl}_{3}(\delta=7.26 \mathrm{ppm})$ and in DMSO- $d_{6}(\delta=2.50 \mathrm{ppm})$. Molecular weights of poly(ester amide)s were determined using a GPC system (HLC-8220, Tosoh, Tokyo, Japan) at AIST. Poly(methyl methacrylate)s were used as standard substances. A column (TSK gel Super HM-N, Tosoh, Tokyo, Japan) was used with HFIP as an eluent $\left(0.2 \mathrm{~mL} / \mathrm{min}, 40^{\circ} \mathrm{C}\right)$. The $T_{\mathrm{m}}$ and $T_{\mathrm{g}}$ of the poly(ester amide)s were measured by DSC (DSC-6220, Seiko Instruments, Tokyo, Japan). TG was performed using TG/DTA-6300 (Seiko Instruments, Tokyo, Japan) in a nitrogen stream.

\subsection{Synthesis of Ditosylates of Diesterdiamines}

GABA (40 mmol), $\mathrm{TsOH} \cdot \mathrm{H}_{2} \mathrm{O}(40.0 \mathrm{mmol})$, and diol $(20.0 \mathrm{mmol})$ were added to toluene $(70 \mathrm{~mL})$ in a reactor with Dean-Stark equipment (Asahi Glassplant Inc., Arao, Japan). The mixture was stirred and refluxed for $24 \mathrm{~h}$ at $130^{\circ} \mathrm{C}$ with removing water. The solution was evaporated under reduced pressure and the residue was recrystallized from EtOH. Filtration and evaporation of the solution gave ditosylate monomers as white solids.

gEg-OTs: $89 \%$ yield. ${ }^{1} \mathrm{H}$ NMR (DMSO- $d_{6}, 500 \mathrm{MHz}$, r.t.) $\delta 7.63\left(\mathrm{br}, 6 \mathrm{H}, \mathrm{NH}_{3}{ }^{+}\right), 7.48(\mathrm{~d}, 4 \mathrm{H}$, $\left.J=8 \mathrm{~Hz}, \mathrm{TsO}^{-}\right), 7.12\left(\mathrm{~d}, 4 \mathrm{H}, J=8 \mathrm{~Hz}, \mathrm{TsO}^{-}\right), 4.24\left(\mathrm{~s}, 4 \mathrm{H}, \mathrm{OCH}_{2} \mathrm{CH}_{2} \mathrm{O}\right), 2.82(\mathrm{t}, 4 \mathrm{H}, J=7 \mathrm{~Hz}$, $\left.\mathrm{COCH}_{2} \mathrm{CH}_{2} \mathrm{CH}_{2} \mathrm{NH}_{3}{ }^{+}\right), 2.42\left(\mathrm{t}, 4 \mathrm{H}, \mathrm{J}=7 \mathrm{~Hz}, \mathrm{COCH}_{2} \mathrm{CH}_{2} \mathrm{CH}_{2} \mathrm{NH}_{3}{ }^{+}\right), 2.29\left(\mathrm{~s}, 6 \mathrm{H}, \mathrm{TsO}^{-}\right), 1.79(\mathrm{~m}, 4 \mathrm{H}$, $J=7 \mathrm{~Hz}, \mathrm{COCH}_{2} \mathrm{CH}_{2} \mathrm{CH}_{2} \mathrm{NH}_{3}{ }^{+}$).

gPg-OTs: $41 \%$ yield. ${ }^{1} \mathrm{H}$ NMR (DMSO-d $6,500 \mathrm{MHz}$, r.t.) $\delta 7.73\left(\mathrm{br}, 6 \mathrm{H}, \mathrm{NH}_{3}{ }^{+}\right), 7.48(\mathrm{~d}, 4 \mathrm{H}$, $\left.J=8 \mathrm{~Hz} \mathrm{TsO}^{-}\right), 7.12\left(\mathrm{~d}, 4 \mathrm{H}, J=8 \mathrm{~Hz}, \mathrm{TsO}^{-}\right), 4.07\left(\mathrm{t}, 4 \mathrm{H}, J=6 \mathrm{~Hz}, \mathrm{OCH}_{2} \mathrm{CH}_{2} \mathrm{CH}_{2} \mathrm{O}\right), 2.82(\mathrm{t}, 4 \mathrm{H}, J=7 \mathrm{~Hz}$, $\left.\mathrm{COCH}_{2} \mathrm{CH}_{2} \mathrm{CH}_{2} \mathrm{NH}_{3}{ }^{+}\right), 2.43\left(\mathrm{t}, 2 \mathrm{H}, \mathrm{J}=7 \mathrm{~Hz}, \mathrm{COCH}_{2} \mathrm{CH}_{2} \mathrm{CH}_{2} \mathrm{NH}_{3}{ }^{+}\right), 2.29\left(\mathrm{~s}, 6 \mathrm{H}, \mathrm{Ts} \mathrm{O}^{-}\right), 1.88(\mathrm{~m}, 2 \mathrm{H}$, $\left.J=6 \mathrm{~Hz}, \mathrm{OCH}_{2} \mathrm{CH}_{2} \mathrm{CH}_{2} \mathrm{O}\right), 1.76\left(\mathrm{~m}, 4 \mathrm{H}, \mathrm{J}=7 \mathrm{~Hz}, \mathrm{COCH}_{2} \mathrm{CH}_{2} \mathrm{CH}_{2} \mathrm{NH}_{3}{ }^{+}\right)$.

gBg-OTs: $81 \%$ yield. ${ }^{1} \mathrm{H}$ NMR (DMSO- $d_{6}, 500 \mathrm{MHz}$, r.t.) $\delta 7.73$ (br, 6H, $\left.\mathrm{NH}_{3}{ }^{+}\right), 7.48(\mathrm{~d}, 4 \mathrm{H}$, $\left.J=8 \mathrm{~Hz}_{2} \mathrm{TsO}^{-}\right), 7.12\left(\mathrm{~d}, 4 \mathrm{H}, J=8 \mathrm{~Hz}, \mathrm{TsO}^{-}\right), 4.04\left(\mathrm{t}, 4 \mathrm{H}, J=6 \mathrm{~Hz}, \mathrm{OCH}_{2} \mathrm{CH}_{2} \mathrm{CH}_{2} \mathrm{CH}_{2} \mathrm{O}\right), 2.82(\mathrm{t}, 4 \mathrm{H}$, $\left.J=7 \mathrm{~Hz}, \mathrm{COCH}_{2} \mathrm{CH}_{2} \mathrm{CH}_{2} \mathrm{NH}_{3}{ }^{+}\right), 2.43\left(\mathrm{t}, 2 \mathrm{H}, J=7 \mathrm{~Hz}, \mathrm{COCH}_{2} \mathrm{CH}_{2} \mathrm{CH}_{2} \mathrm{NH}_{3}{ }^{+}\right), 2.29\left(\mathrm{~s}, 6 \mathrm{H}, \mathrm{TsO}^{-}\right), 1.76$ $\left(\mathrm{m}, 4 \mathrm{H}, \mathrm{J}=7 \mathrm{~Hz}, \mathrm{COCH}_{2} \mathrm{CH}_{2} \mathrm{CH}_{2} \mathrm{NH}_{3}{ }^{+}\right), 1.60\left(\mathrm{~m}, 4 \mathrm{H}, \mathrm{OCH}_{2} \mathrm{CH}_{2} \mathrm{CH}_{2} \mathrm{CH}_{2} \mathrm{O}\right)$.

\subsection{Synthesis of Sequential Poly(Ester Amide)s with GABA Unit}

A tosylate salt of alkylene bis( $\gamma$-aminobutyrate) (gEg-OTs, gPg-OTs, or gBg-OTs) (0.14 mmol) and $\operatorname{di}(p$-nitrophenyl) ester (T-NP, N-NP, S-NP, G-NP, or A-NP) $(0.14 \mathrm{mmol})$ were dissolved in DMSO $(4 \mathrm{~mL})$. This mixture was heated to $70{ }^{\circ} \mathrm{C}$ and $\mathrm{Et}_{3} \mathrm{~N}(7.0 \mathrm{mmol})$ was added to the solution. The mixture was stirred for $24 \mathrm{~h}$ at $70{ }^{\circ} \mathrm{C}$. Then the resulting mixture was poured into excess EtOAc to precipitate the polymer, which was filtered and dried in vacuum.

The yields and molecular weights of the obtained polymers are summarized in Table $1 .{ }^{1} \mathrm{H}$ NMR spectra of the obtained polymers are shown in supporting materials.

\subsection{Biodegradation Tests of the Poly(Ester Amide)s in Seawater and in Activated Sludge}

The poly(ester amide)s were treated by frost shattering to make them into fine powders. Biodegradation lab tests of the poly(ester amide)s in seawater and in activated sludge were evaluated from oxygen consumption using BOD tester (BOD200F, TAITEC, Koshigaya, Japan) according to the previous paper [54]. Seawater was collected from Osaka South Port bay area [10]. A standard activated sludge was provided from the Chemicals Evaluation and Research Institute, Tokyo, Japan. The typical procedure is as follows: polymer specimens $(30 \mathrm{mg})$ were added into $250 \mathrm{~mL}$ BOD testing bottle and then seawater $(200 \mathrm{~mL})$ or the activated sludge $(200 \mathrm{~mL})$ was added. Evolved $\mathrm{CO}_{2}$ was removed by $\mathrm{Ca}(\mathrm{OH})_{2}$ from the BOD closed system. The biodegradation test was carried out at $27^{\circ} \mathrm{C}$ with stirring for 1 month. The observed $\mathrm{O}_{2}$ consumption volume was corrected by subtraction to $\mathrm{O}_{2}$ consumption volume of control. The theoretical amount of consumed $\mathrm{O}_{2}(\mathrm{~mL})$ means the total $\mathrm{O}_{2}$ that should be consumed on complete degradation of sample. Biodegradation (\%) was calculated as follows: 
In the case of poly $(\mathrm{gEgT})$, the theoretical consumption of $\mathrm{O}_{2}$ is the following Equation (1), and the biodegradation is estimated by Equation (2):

$$
\mathrm{C}_{20} \mathrm{H}_{26} \mathrm{~N}_{2} \mathrm{O}_{6}+26 \mathrm{O}_{2} \rightarrow 20 \mathrm{CO}_{2}+12 \mathrm{H}_{2} \mathrm{O}+2 \mathrm{HNO}_{3}
$$

Biodegradation $(\%)=\left[\right.$ experimentally consumed $\mathrm{O}_{2}(\mathrm{~mL}) /$ theoretical $\left.\mathrm{O}_{2}(\mathrm{~mL})\right] \times 100$

The biodegradation value (\%) was average value of duplicate data $(n=2)$.

\section{Conclusions}

We succeeded in synthesizing a series of new poly(ester amide)s containing GABA unit and observed their relatively higher $T_{\mathrm{m}}$ in comparison with those of typical aliphatic polyesters. Compared with PA4, the processability of these poly(ester amide)s were improved. Aliphatic poly(ester amide)s containing ethylene glycol or 1,3-propanediol units showed moderate biodegradability in seawater. Poly(gEgT) was found to show relatively high biodegradability in seawater among the aromatic poly(ester amide)s. Aliphatic poly(ester amide)s containing ethylene glycol unit also exhibited moderate biodegradability in activated sludge. However, the present synthetic method of the poly(ester amide)s is not desirable for their industrial production and the molecular weights of the products are not high enough for most applications. A better synthetic method is desired for their practical application.

Supplementary Materials: Supplementary materials can be found at http://www.mdpi.com/1422-0067/21/10/3674/s1.

Author Contributions: Conceptualization, Y.N.; Data curation, K.W.; Formal analysis, N.K.; Funding acquisition, Y.N. and T.S.; Investigation, K.W., N.K., N.Y. and A.N.; Methodology, Y.N., K.W., R.T. and A.N.; Project administration, Y.N.; Resources, Y.N., R.T., T.S. and A.N.; Supervision, Y.N. and T.S.; Validation, Y.N.; Visualization, Y.N. and K.W.; Writing—original draft, Y.N. and K.W.; Writing—review and editing, Y.N., R.T. and T.S. All authors have read and agreed to the published version of the manuscript.

Funding: This research received no external funding.

Conflicts of Interest: The authors declare no conflict of interest.

\section{Abbreviations}

\begin{tabular}{|c|c|}
\hline GABA & $\gamma$-Aminobutyric acid \\
\hline PA4 & Polyamide 4 \\
\hline PHA & Poly(3-hydroxyalkanoate) \\
\hline PLLA & Poly(L-lactic acid) \\
\hline PGA & Poly(glycolic acid) \\
\hline PCL & Poly(E-caprolactone) \\
\hline PBS & Poly(butylene succinate) \\
\hline PET & Poly(butylene succinate) \\
\hline$T_{\mathrm{m}}$ & Melting temperature \\
\hline$T_{\mathrm{g}}$ & Glass-transition temperature \\
\hline $\mathrm{TsOH} \cdot \mathrm{H}_{2} \mathrm{O}$ & $p$-Toluenesulfonic acid monohydrate \\
\hline gEg-OTs & Ditosylate of ethylene bis( $\gamma$-aminobutyrate) \\
\hline gPg-OTs & Ditosylate of trimethylene bis( $\gamma$-aminobutyrate) \\
\hline gBg-OTs & Ditosylate of butylene bis( $\gamma$-aminobutyrate) \\
\hline T-NP & $\operatorname{Bis}(p$-nitrophenyl) terephthalate \\
\hline N-NP & $\operatorname{Bis}(p$-nitrophenyl) 2.6-naphthalenedicarboxylate \\
\hline S-NP & $\operatorname{Bis}(p$-nitrophenyl) succinate \\
\hline Gl-NP & $\operatorname{Bis}(p$-nitrophenyl) glutarate \\
\hline A-NP & $\operatorname{Bis}(p$-nitrophenyl) adipate \\
\hline DMSO & Dimethyl sulfoxide \\
\hline THF & Tetrahydrofuran \\
\hline HFIP & 1,1,1,3,3,3-Hexafluoro-2-propanol \\
\hline GPC & Gel permeation chromatography \\
\hline PMMA & Poly(methyl methacrylate) \\
\hline
\end{tabular}




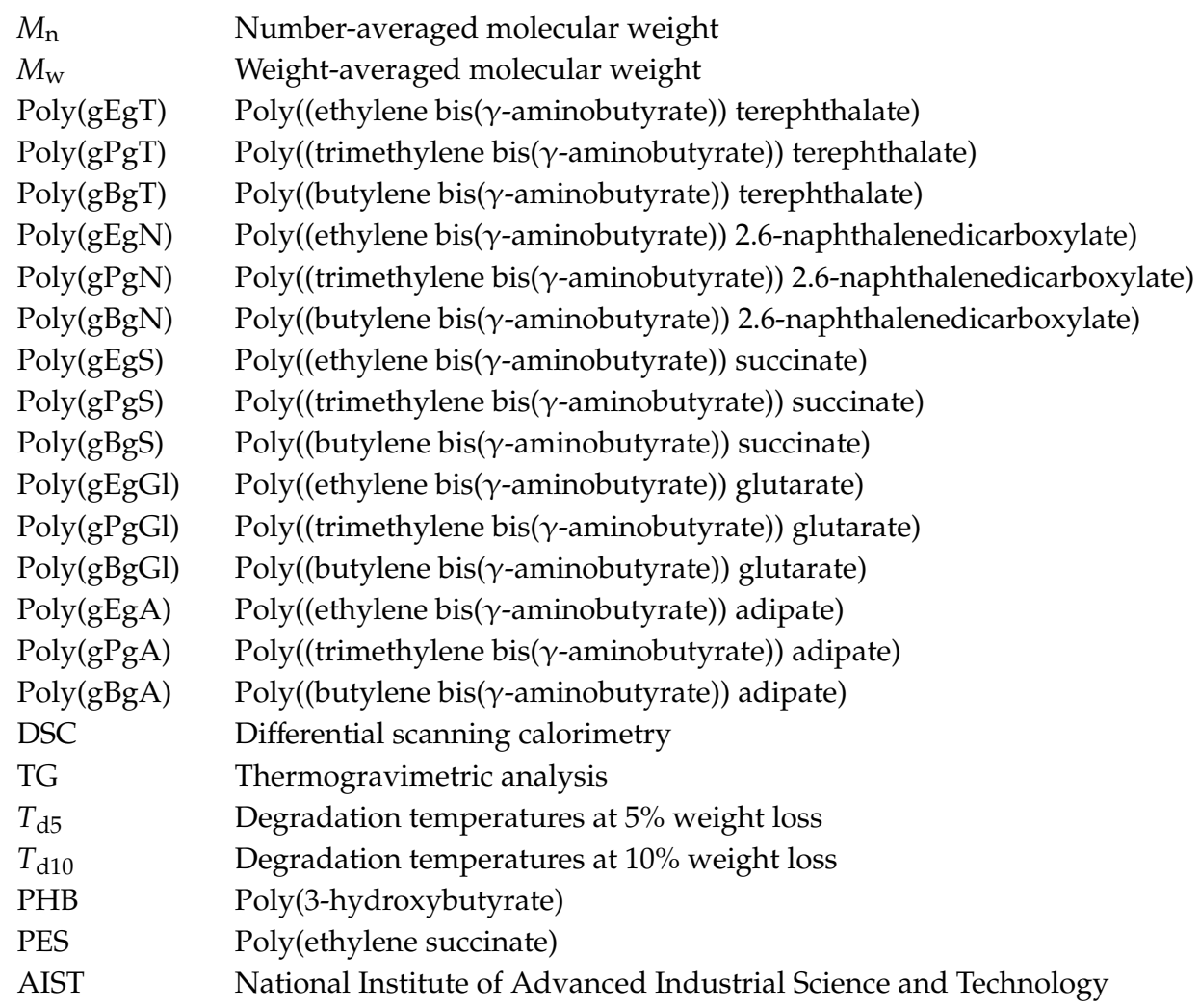

\section{References}

1. Mallapragada, S.K.; Narasimhan, B. Handbook of Biodegradable Polymeric Materials and Their Applications; American Scientific Publishers: Stevenson Ranch, CA, USA, 2005.

2. Narancic, T.; Verstichel, S.; Chaganti, S.R.; Morales-Gamez, L.; Kenny, S.T.; Wilde, B.D.; Padamati, R.B.; O'Connor, K.E. Biodegradable Plastic Blends Create New Possibilities for End-of-Life Management of Plastics but They Are Not a Panacea for Plastic Pollution. Environ. Sci. Technol. 2018, 52, 10441-10452. [CrossRef]

3. Haider, T.P.; Völker, C.; Kramm, J.; Landfester, K.; Wurm, F.R. Plastics of the Future? The Impact of Biodegradable Polymers on the Environment and on Society. Angew. Chem. Int. Ed. 2019, 58, 50-62. [CrossRef] [PubMed]

4. Agarwal, S. Biodegradable Polymers: Present Opportunities and Challenges in Providing a Microplastic-Free Environment. Macromol. Chem. Phys. 2020, 221, 2000017. [CrossRef]

5. Jambeck, J.R.; Geyer, R.; Wilcox, C.; Siegler, T.R.; Perryman, M.; Andrady, A.; Narayan, R.; Law, K.L. Plastic waste inputs from land into the ocean. Science 2015, 347, 768-771. [CrossRef] [PubMed]

6. Lönnstedt, O.M.; Eklöv, P. Environmentally relevant concentrations of microplastic particles influence larval fish ecology. Science 2016, 352, 1213-1216. [CrossRef]

7. Isobe, A.; Iwasaki, S.; Uchida, K.; Tokai, T. Abundance of non-conservative microplastics in the upper ocean from 1957 to 2066. Nat. Commun. 2019, 10, 417. [CrossRef]

8. Volova, T.G.; Boyandin, A.N.; Vasiliev, A.D.; Karpov, V.A.; Prudnikova, S.V.; Mishukova, O.V.; Boyarskikh, U.A.; Filipenko, M.L.; Rudnev, V.P.; Xuân, B.B.; et al. Biodegradation of polyhydroxyalkanoates (PHAs) in tropical coastal waters and identification of PHA-degrading bacteria. Polym. Degrad. Stab. 2010, 95, 2350-2359. [CrossRef]

9. Bagheri, A.R.; Laforsch, C.; Greiner, A.; Agarwal, S. Fate of So-Called Biodegradable Polymers in Seawater and Freshwater. Glob. Chall. 2017, 1, 1700048. [CrossRef]

10. Nakayama, A.; Yamano, N.; Kawasaki, N. Biodegradation in seawater of aliphatic polyesters. Polym. Degrad. Stab. 2019, 166, 290-299. [CrossRef]

11. Yoshida, S.; Hiraga, K.; Takehana, T.; Taniguchi, I.; Yamaji, H.; Maeda, Y.; Toyohara, K.; Miyamoto, K.; Kimura, Y.; Oda, K. A bacterium that degrades and assimilates poly(ethylene terephthalate). Science 2016, 351, 1196-1199. [CrossRef] 
12. Nakayama, Y.; Yagumo, W.; Tanaka, R.; Shiono, T.; Inumaru, K.; Tsutsumi, C.; Kawasaki, N.; Yamano, N.; Nakayama, A. Synthesis, properties and biodegradation of periodic copolyesters composed of hydroxy acids, ethylene glycol, and terephthalic acid. Polym. Degrad. Stab. 2020, 174, 109095. [CrossRef]

13. Hashimoto, S.; Yamane, K.; Wakabayashi, J.; Matsui, H. Filament of Polyglycolic Acid Resin and Process for Producing the Same. U.S. Patent 2010/0148391 A1, 17 June 2010.

14. Tsuji, H.; Suzuyoshi, K. Environmental degradation of biodegradable polyesters 1. Poly( $\varepsilon$-caprolactone), poly[(R)-3-hydroxybutyrate], and poly(L-lactide) films in controlled static seawater. Polym. Degrad. Stab. 2002, 75, 347-355. [CrossRef]

15. Krasowska, K.; Brzeska, J.; Rutkowska, M.; Dacko, P.; Sobota, M.; Kowalczuk, M. The effect of poly(D,L-lactide) modification with poli[(R,S)-3-hydroxybutyrate] on the course of its degradation in natural environments. Polimery 2008, 53, 730-736. [CrossRef]

16. Chen, X.; Wang, L.; Shi, J.; Shi, H.; Liu, Y. Environmental degradation of starch/poly(lactic acid) composite in seawater. Polym. Polym. Compos. 2011, 19, 559-565. [CrossRef]

17. Yamano, N.; Kawasaki, N.; Takeda, S.; Nakayama, A. Production of 2-Pyrrolidone from Biobased Glutamate by Using Escherichia coli. J. Polym. Environ. 2013, 21, 528-533. [CrossRef]

18. Hashimoto, K.; Hamano, T.; Okada, M. Degradation of several polyamides in soils. J. Appl. Polym. Sci. 1994, 54, 1579-1583. [CrossRef]

19. Kawasaki, N.; Nakayama, A.; Yamano, N.; Takeda, S.; Kawata, Y.; Yamamoto, N.; Aiba, S.-I. Synthesis, thermal and mechanical properties and biodegradation of branched polyamide 4. Polymer 2005, 46, 9987-9993. [CrossRef]

20. Yamano, N.; Nakayama, A.; Kawasaki, N.; Yamamoto, N.; Aiba, S. Mechanism and Characterization of Polyamide 4 Degradation by Pseudomonas sp. J. Polym. Environ. 2008, 16, 141-146. [CrossRef]

21. Tachibana, K.; Hashimoto, K.; Yoshikawa, M.; Okawa, H. Isolation and characterization of microorganisms degrading nylon 4 in the composted soil. Polym. Degrad. Stab. 2010, 95, 912-917. [CrossRef]

22. Tachibana, K.; Urano, Y.; Numata, K. Biodegradability of nylon 4 film in a marine environment. Polym. Degrad. Stab. 2013, 98, 1847-1851. [CrossRef]

23. Yamano, N.; Kawasaki, N.; Ida, S.; Nakayama, Y.; Nakayama, A. Biodegradation of polyamide 4 in vivo. Polym. Degrad. Stab. 2017, 137, 281-288. [CrossRef]

24. Tachibana, K.; Hashimoto, K.; Tansho, N.; Okawa, H. Chemical modification of chain end in nylon 4 and improvement of its thermal stability. J. Polym. Sci. Part A Polym. Chem. 2011, 49, 2495-2503. [CrossRef]

25. Goodman, I.; Sheahan, R.J. Copolyesteramides-V. Hexamethylene adipamide/hexamethylene adipate random and ordered copolymers: Preparation and general properties. Eur. Polym. J. 1990, 26, 1081-1088. [CrossRef]

26. Murthy, N.S.; Aharoni, S.M. Structural studies of liquid-crystalline poly(ester amides). Macromolecules 1992, 25, 1177-1183. [CrossRef]

27. Pivsa-Art, S.; Nakayama, A.; Kawasaki, N.; Yamamoto, N.; Aiba, S. Biodegradability study of copolyesteramides based on diacid chlorides, diamines, and diols. J. Appl. Polym. Sci. 2002, 85, 774-784. [CrossRef]

28. Puiggalí, J.; Subirana, J.A. Synthetic polymers containing $\alpha$-amino acids: From polyamides to poly(ester amide)s. J. Pept. Sci. 2005, 11, 247-249. [CrossRef]

29. Gomurashvili, Z.; Zhang, H.; Da, J.; Jenkins, T.D.; Hughes, J.; Wu, M.; Lambert, L.; Grako, K.A.; DeFife, K.M.; MacPherson, K.; et al. From Drug-Eluting Stents to Biopharmaceuticals: Poly(ester amide) a Versatile New Bioabsorbable Biopolymer. In Polymers for Biomedical Applications; ACS Publications: Washington, DC, USA, 2008; pp. 10-26.

30. Fonseca, A.C.; Gil, M.H.; Simões, P.N. Biodegradable poly(ester amide)s-A remarkable opportunity for the biomedical area: Review on the synthesis, characterization and applications. Prog. Polym. Sci. 2014, 39, 1291-1311. [CrossRef]

31. Díaz, A.; Katsarava, R.; Puiggalí, J. Synthesis, Properties and Applications of Biodegradable Polymers Derived from Diols and Dicarboxylic Acids: From Polyesters to Poly(ester amide)s. Int. J. Mol. Sci. 2014, 15, 7064-7123. [CrossRef]

32. Ghosal, K.; Latha, M.S.; Thomas, S. Poly(ester amides) (PEAs)—Scaffold for tissue engineering applications. Eur. Polym. J. 2014, 60, 58-68. [CrossRef]

33. Winnacker, M.; Rieger, B. Poly(ester amide)s: Recent insights into synthesis, stability and biomedical applications. Polym. Chem. 2016, 7, 7039-7046. [CrossRef] 
34. NgaNguyen, T.H.; Balligand, F.; Bormann, A.; Bennevault, V.; Guégan, P. Synthesis of new biobased linear poly(ester amide)s. Eur. Polym. J. 2019, 121, 109314. [CrossRef]

35. Grigat, E.; Koch, R.; Timmermann, R. BAR 1095 and BAK 2195: Completely biodegradable synthetic thermoplastics. Polym. Degrad. Stab. 1998, 59, 223-226. [CrossRef]

36. Asín, L.; Armelin, E.; Montané, J.; Rodríguez-Galán, A.; Puiggalí, J. Sequential poly(ester amide)s based on glycine, diols, and dicarboxylic acids: Thermal polyesterification versus interfacial polyamidation. Characterization of polymers containing stiff units. J. Polym. Sci. Part A Polym. Chem. 2001, 39, 4283-4293. [CrossRef]

37. Yamano, N.; Kawasaki, N.; Ida, S.; Nakayama, A. Biodegradation of polyamide 4 in seawater. Polym. Degrad. Stab. 2019, 166, 230-236. [CrossRef]

38. Lutz, J.-F.; Ouchi, M.; Liu, D.R.; Sawamoto, M. Sequence-Controlled Polymers. Science 2013, 341, 1238149. [CrossRef] [PubMed]

39. Shaffer, T.D.; Canich, J.A.M.; Squire, K.R. Metallocene-Catalyzed Copolymerization of Ethylene and Isobutylene to Substantially Alternating Copolymers. Macromolecules 1998, 31, 5145-5147. [CrossRef]

40. Katsarava, R.; Beridze, V.; Arabuli, N.; Kharadze, D.; Chu, C.C.; Won, C.Y. Amino acid-based bioanalogous polymers. Synthesis, and study of regular poly(ester amide)s based on bis( $\alpha$-amino acid) $\alpha, \omega$-alkylene diesters, and aliphatic dicarboxylic acids. J. Polym. Sci. Part A Polym. Chem. 1999, 37, 391-407. [CrossRef]

41. Atkins, K.M.; Lopez, D.; Knight, D.K.; Mequanint, K.; Gillies, E.R. A versatile approach for the syntheses of poly(ester amide)s with pendant functional groups. J. Polym. Sci. Part A Polym. Chem. 2009, 47, 3757-3772. [CrossRef]

42. Yamada, Y.; Yoshida, M. Preparation of Diamine Derivatives Having Naphthalene Skeleton. JP Patent 1991-279350, 10 December 1991.

43. Ashley, J.N.; Collins, R.F.; Davis, M.; Sirett, N.E. 673. The chemotherapy of schistosomiasis. Part I. Derivatives and analogues of $\alpha \omega$-di-(p-aminophenoxy)alkanes. J. Chem. Soc. 1958, 3298-3313. [CrossRef]

44. Arabuli, N.; Tsitlanadze, G.; Edilashvili, L.; Kharadze, D.; Goguadze, T.; Beridze, V.; Gomurashvili, Z.; Katsarava, R. Heterochain polymers based on natural amino acids. Synthesis and enzymatic hydrolysis of regular poly(ester amide)s based on bis(L-phenylalanine) $\alpha, w$-alkylene diesters and adipic acid. Macromol. Chem. Phys. 1994, 195, 2279-2289. [CrossRef]

45. Hill, R.; Walker, E.E. Polymer constitution and fiber properties. J. Polym. Sci. Part A Gen. Pap. 1948, 3, 609-630. [CrossRef]

46. Bunn, C.W. The melting points of chain polymers. J. Polym. Sci. 1955, 16, 323-343. [CrossRef]

47. Brandrup, J.; Immergut, E.H.; Grulke, E.A. Polymer Handbook, 4th ed.; John Wiley \& Sons: New York, NY, USA, 2003.

48. Jin, X.; Ellis, T.S.; Karasz, F.E. Studies on the water induced plasticization behavior of nylon 4. The influence of crystallinity and radiation crosslinking. Makromol. Chem. 1985, 186, 191-201. [CrossRef]

49. Zuo, J.; Li, S.; Bouzidi, L.; Narine, S.S. Thermoplastic polyester amides derived from oleic acid. Polymer 2011, 52, 4503-4516. [CrossRef]

50. Ge, Y.P.; Yuan, D.; Luo, Z.L.; Wang, B.B. Synthesis and characterization of poly(ester amide) from remewable resources through melt polycondensation. Express Polym. Lett. 2014, 8, 50-54. [CrossRef]

51. Kasuyaa, K.-I.; Takagi, K.-I.; Ishiwatari, S.-I.; Yoshida, Y.; Doi, Y. Biodegradabilities of various aliphatic polyesters in natural waters. Polym. Degrad. Stab. 1998, 59, 327-332. [CrossRef]

52. Maeda, Y.; Nakayama, A.; Kawasaki, N.; Hayashi, K.; Aiba, S.; Yamamoto, N. Properties and biodegradability of chain-extended copoly(succinic anhydride/ethylene oxide). J. Environ. Polym. Degrad. 1996, 4, 225-233. [CrossRef]

53. Yoo, E.S.; Im, S.S.; Yoo, Y. Morphology and degradation behavior of aliphatic/aromatic copolyesters. Macromol. Symp. 1997, 118, 739-745. [CrossRef]

54. Sashiwa, H.; Kawasaki, N.; Nakayama, A.; Muraki, E.; Yamamoto, N.; Zhu, H.; Nagano, H.; Omura, Y.; Saimoto, H.; Shigemasa, Y.; et al. Chemical Modification of Chitosan. 13. Synthesis of Organosoluble, Palladium Adsorbable, and Biodegradable Chitosan Derivatives toward the Chemical Plating on Plastics. Biomacromolecules 2002, 3, 1120-1125. [CrossRef]

(C) 2020 by the authors. Licensee MDPI, Basel, Switzerland. This article is an open access article distributed under the terms and conditions of the Creative Commons Attribution (CC BY) license (http://creativecommons.org/licenses/by/4.0/). 